\title{
BRITISH OXYGEN CANADA PRIZE
}

British Oxygen Canada Limited have made available the sum of $\$ 1,000$ annually for a prize to be awarded by the Canadian Anaesthetists' Society for the best original work in Anaesthesia completed in Canada during the year preceding the award. The first such prize will be awarded at the time of the Annual Meeting of the Canadian Anaesthetists' Society in 1961. The following regulations apply:

\section{Qualifications}

(1) Applicant must be a resident in training in Anaesthesia or a prajctising anaesthetist.

(2) The study must be carried out in a Canadian Hospital or University, and must have been completed during the previous 12 months.

(3) The study submitted may be of a basic or clinical nature.

\section{Submission and Selection}

(1) Applicant's study is to be submitted in quadruplicate to the Secretary, Canadian Anaesthetists' Society, prior to April 1.

(2). Three (3) referees will be appointed by the Executive of the Canadian Anaesthetists' Society from departments of Anaesthesia in Canadian Universities. Not more than one refere shall be chosen from any one University.

(3) The prize-winning report or reports 4 all be presented at the Annual Meeting of the Canadian Anaesthetists' Society at which the award will be made, and will be subject to exclusive publication in the Canadian Anaesthetists' Society Journal. The right of publication of all reports submitted in application for the prize is reservêd to the Canadian Anaesthetists' Society Journal subject to acceptance by the Editor.

(4). In the event of two (2) applicants submitting work judged by the referees to be of equal merit, the award may be divided at the discretion of the referees.

(5) If in the opinion of the referees the studies submitted do not wartant the award being made in any year, the prize will be deferred. 